\title{
Study on the Cultivation of Innovative Enterprise Ability of Higher Vocational Students
}

\section{Dong Li}

Xi’an Aeronautical Polytechnic Institute, Xi’an, Shaanxi, 710089

\author{
Keywords: Cultivation Method, Innovative Enterprise Ability, Higher Vocational Students
}

\begin{abstract}
It is the mission entrusted by the times to cultivate high vocational students' ability to innovate and start their own business. It is the motivation to make the higher vocational education full of vitality and create distinctive features. Based on the researches both at home and abroad, combined with the status quo of cultivating students' ability of innovation and entrepreneurship in higher vocational colleges in China, this paper puts forward the feasible path of cultivating innovative entrepreneurship ability by cultivating innovative and applied technical and skill-based talents and cultivating innovative talents Program, building a practical training base, with innovative faculty, reform of examination methods.
\end{abstract}

\section{Introduction}

The research on innovation and entrepreneurship is receiving great attention both at home and abroad. Many domestic scholars engaged in research on innovation and entrepreneurship have published a large number of articles on theories, systems and approaches. For example, Shi Xianfeng wrote the article titled "Cultivating College Students' Ability of Innovation and Entrepreneurship Practice and exploration, "the article proposes that the main content of higher education reform is to enhance the ability of students to innovate and start their own business, and realize the value of college students through innovation and entrepreneurship. In foreign countries, innovation and entrepreneurship education should be incorporated into the national policy of national development. The British White Paper in "The Future of Our Competitive Future: Building a Knowledge-Driven Economy" published by the British Government in 1998 stated that "to succeed in entrepreneurship education, we must have a stable financial and economic background, a social and business environment that supports entrepreneurship, education Sophisticated and skilled team, entrepreneurship education will be successful. " Based on the previous studies, this paper, based on the actual conditions of college students in higher vocational colleges, combined with the current situation, to study specific ways to enhance students' ability of innovation and entrepreneurship and establish the corresponding implementation system.

\section{Analysis on the Status Quo of Higher Vocational Students' Innovation and Entrepreneurship Training}

First, inadequate institutional innovation. Although there are innovations in the system of higher vocational colleges, due to the short reform period and the shackles of traditional concepts and models, system innovation is restricted. Teaching management, teaching methods, enrollment and employment still follow the existing model, to limit the personality development of students and enhance their ability to innovate, innovation and entrepreneurial ability to cultivate the flow of forms, there is no breakthrough and progress. Thunder, rain small phenomenon exists everywhere. Second, teaching methods and teaching content behind. The current overall situation of colleges and universities in Xi'an City are all to enhance innovation and entrepreneurship as a key focus, but also to develop some relevant implementation measures, but in the specific implementation of the time there are major problems. Such as teaching methods and teaching content there is a serious lag phenomenon, and far away from training innovative entrepreneurship talent requirements. Many teachers in the lecture process is still using a chalk 1 book 1 full house, teaching content is not with 
the times, seriously restricting the students' thinking and creativity. Third, teachers lack the capacity of innovation and entrepreneurship. Teachers are the key to cultivating students 'ability to innovate and start a business. However, the actual situation is that the teachers themselves have no entrepreneurial experience, lack of innovation, being influenced by various things and titles, and cultivating students' innovation and entrepreneurship has also become a slogan. There is not enough support for teacher innovation and entrepreneurship training in colleges and universities, there is no perfect institutional mechanism to encourage teachers to innovate and start a business, and there are not enough conditions to guarantee teachers' innovation and entrepreneurship so as to restrict teachers' ability to innovate and train students' lack of stamina.

\section{Higher Vocational Colleges and Universities Students Innovation and Entrepreneurship Capability Dilemmas}

To cultivate students' ability of innovation and entrepreneurship, it is necessary to require vocational colleges to carry out a series of reforms, including the reform of personnel training mode, the reform of curriculum system and the reform of teaching management system. However, school personnel training differs from the production of a company's products. Once the product is produced, consumers can get immediate feedback from the market. If the product quality is not high enough or does not meet the needs of consumers, the enterprise will face a crisis of survival. Forcing companies to keep up with the market demand and timely improve product design Or production process. However, the graduates trained by higher vocational colleges are not easily reflected in the level of short-term, and the influencing factors of the process of talent development include not only school education, but also personal talents and foundations, efforts and opportunities, which are not easy to be attributed to It is difficult for higher vocational colleges to form a business-like mechanism. This is why many educational reforms, though massive and difficult to be truly promoted in reality, can survive without or with the reform of higher vocational colleges and thus lack the impetus of reform.

To cultivate students' ability to innovate and start their own business, schools need to provide various conditions such as: a large number of teachers teaching students, a high quality innovation and entrepreneurship course for students to read, rich paper or electronic materials for students, advanced Training experimental equipment and sufficient experimental training supplies for students to use, a wide range of entrepreneurial projects for students to practice and so on. To cultivate students' capability of innovation and entrepreneurship, the above conditions must be met, and the implementation of each condition requires a large investment, but the sources of funding and the amount of funding for higher vocational colleges are basically fixed. The existing teaching funds can only meet the needs of schools For daily operation, it is hard to have more funds to train students' innovation and entrepreneurship ability.

The teaching management system in the past to more consider the cost and efficiency of management, mainly from the perspective of convenience managers. However, the students who carry out the innovation and entrepreneurship are different in their learning progress, curriculum arrangement and resource utilization, which inevitably lead to the suspension of study or slow down of learning due to the start-up. Therefore, the cultivation of students' innovation and entrepreneurship requires teaching management to be more Flexibility and flexibility, more from the students need to develop innovative entrepreneurship. For example, the credit system in place of the full credit system for the academic credit system, class management in accordance with the degree of student learning formed non-fixed teaching instead of admission to the graduation are fixed administrative classes, the curriculum from the compulsory most accounted for Elective more than required courses, classrooms, training room management from the regular opening into an open 24 hours a day, and so on. Vocational colleges to change the original teaching management system, will inevitably lead to increased management costs and management efficiency, management workload and more difficult, of which the biggest resistance comes from the management itself.

Facing the multiple pressures of teaching, scientific research and living, teachers can not 
cultivate students' ability of innovation and entrepreneurship. Teachers in higher vocational colleges not only need to complete certain teaching tasks, but also complete a large number of scientific research tasks, such as declaring subjects, writing essays and applying for patents. Otherwise, they can not pass the title assessment. In particular, middle-aged and young teachers, who account for most of the teachers in higher vocational colleges, face many challenges in life such as marriage and funeral, marriage and funeral, childbearing and children's education while facing the dual pressures of teaching and scientific research. Take into account the ability of students to develop innovative entrepreneurship.

Teachers 'ability to innovate and start their own businesses is not strong and it is hard to train students' ability to innovate and start a business. "Blacksmith also needs its own hard", to train students' ability of innovation and entrepreneurship, teachers must first require a strong ability to innovation and entrepreneurship. However, subject to the qualifications of teachers employed, the majority of teachers in higher vocational colleges directly enter the teaching profession after graduating from colleges and universities, with little or no actual working experience in the enterprises. These teachers have a higher theoretical level, but the lack of practical ability, more difficult to start a successful experience. And innovation and entrepreneurship not only stay in the ideological level, but also should be combined with the reality, the role of practice, which inevitably requires teachers to have a strong operational capacity, the good ideas can be applied to the actual project. Due to the lack of ability of teachers in higher vocational colleges in this aspect, they lead to many theories and less practical guidance in guiding students. Even if teachers have the motivation and enthusiasm to cultivate students' innovation and entrepreneurship, it is hard to produce good results.

\section{To enhance vocational students innovation and entrepreneurship path}

First, to build an innovative application-based technology skilled personnel training model. In order to enhance the creative ability of undergraduates, colleges and universities should continue to deepen the innovation and reform and carry out the model innovation. For example, Germany's "dual system" model, schools and enterprises to build a teaching model, students work half-time format; Britain's "work-study alternative" model, students in the normal During the study, student business practice arrangements, students as a real job to participate in the practice of identity and get the appropriate remuneration.

Second, deepen the personnel training programs and curriculum system reform. The training objectives in the personnel training program should be adjusted. The original training objectives focus on applied talents, and the adjusted training objectives focus on the training of innovative ability, entrepreneurship and technical skills. To provide the basis for innovation and entrepreneurship training and protection. In order to achieve the goal of cultivating innovative entrepreneurship, the curriculum system can be set up in the form of modules and gradual progressively. In the curriculum system to join the basic module of innovation and entrepreneurship, innovation and entrepreneurship skills module, innovation and entrepreneurship expansion module, innovation and entrepreneurship competition module, teacher-student innovation and entrepreneurship interaction module. Each module is joined with the characteristics of innovation and entrepreneurial curriculum content, the various modules of the combination of each course, progressive layers, the ability to train innovation and entrepreneurship throughout the course module.

Third, strengthen the construction of practical training base. Break the original professional restrictions, the implementation of the entire school training room open sharing, unhindered use, to teachers and students to open basic training room and professional training room, training room to protect the open rate and utilization, to guide students to actively participate in the simulation Practice and improve the ability of innovation and entrepreneurship. We should make full use of various resources to build an innovation and entrepreneurship college for undergraduates, a university science park, an incubator for innovation and entrepreneurship, and an innovation and entrepreneurship base for small and micro enterprises. The construction of a number of students 
innovation and entrepreneurship demonstration base, off-campus internship training base, vocational training base and science and technology practice base, the formation of innovation and entrepreneurship practice platform.

Fourth, to create an innovative and entrepreneurial high-quality faculty. First, reduce unnecessary workload of teachers and reduce unnecessary meetings. Teachers should not increase additional tasks for teachers after completing the teaching workload stipulated by the school, and reduce the routine teaching inspection To avoid unnecessary and repetitive work; secondly, to encourage teachers, especially young teachers, to carry out internship in enterprises, regularly participate in training, update their knowledge and expand their horizons. For teacher training, internships to provide funding and time protection, teachers in the process of internships and training in accordance with the normal wage and class work calculations; Third, the establishment of a team of senior experts, with a strong innovation and entrepreneurship guidance full-time teachers. Encourage teachers to participate in entrepreneurial experience and exchange, learn teaching methods and teaching methods about innovation and entrepreneurship education curriculum.

Fifth, to deepen the reform of examination methods. Breaking the original assessment model of the terminal assessment, focusing on process assessment, the actual work process based on the tasks, from all levels of assessment, for each process to design a capacity assessment program. Construction of a comprehensive series of activities and professional skills competitions, to achieve the students in school, high school, to do with the test to match the game, to promote the purpose of the game. In this way, comprehensive ability training is also an overall assessment of students' training effect, and finally an all-round, three-dimensional and dynamic evaluation system for innovation and entrepreneurship is finally established.

\section{Conclusion}

The existing curricula in higher vocational colleges focus on the students' professional knowledge and skills, and must establish and perfect the curriculum system of innovation and entrepreneurship education, which involves the updating of concepts, the breakthrough of thinking and the practical barriers that the entrepreneurial process will face. Through a series of thinking training courses to help students improve their ability to think logically, form innovative ideas and master innovative ways. Through a series of entrepreneurial practice courses, students can master project selection, market analysis, fund management, business location, Document writing, handling procedures, cost control, advertising planning and other entrepreneurial process may face all the practical obstacles to the solution to improve the entrepreneurial combat capabilities, avoid talking about theory but do not solve practical problems.

\section{References}

[1] Xu Chengping. Based on the quality characteristics of vocational students to explore and think in accordance with their aptitude [J]. Education and Careers, 2013 (11).

[2] Chen Hongzhao. On the basis of quality, ability-based entrepreneurship education innovation [J]. Heilongjiang Education: Higher Education Research and Evaluation, 2010 (11).

[3] Wu Yonghui vocational students entrepreneurship education and entrepreneurship training thinking [J] Adult Education, 2009 (5).

[4] Zhong Yanjin. Survey and analysis of the status of implementation of innovative credits in higher vocational colleges [J]. Education and Careers, 2016 (9).

[5] Cao Shuyan. Analysis of Curriculum Construction in Australian Universities [J]. Journal of Henan University (Social Science), 2005, 45 (1): 142-144. 